Chirurgia (2019) 114: 331-342

No. 3, May - June

Copyright $\odot$ Celsius

http://dx.doi.org/10.21614/chirurgia.114.3.331

\title{
Elderly Patients with Colorectal Cancer - A Predisposed Category for Postoperative Complications
}

\author{
Élthes Előd Etele, Daniela Sala, Márton Dénes, Alexandra Cozlea, Ruxandra Darie, Árpád Török
}

$2^{\text {nd }}$ Surgery Department, Mureș County University Hospital, Târgu Mureș, Romania

Corresponding author:

Sala Daniela, MD

Mureș County University Hospital

$2^{\text {nd }}$ Surgery Department

Senior Lecturer of Surgery

University of Medicine and Pharmacy

Târgu Mureș

15, Grigorescu Street, Ap.11

Târgu Mures, Mures, România

E-mail: salatatiana@yahoo.com
Received: 24.05 .2019 Accepted: 12.06 .2019

\section{Rezumat}

Pacienti vârstnici cu cancer colorectal - o categorie predispusă la complicatii postoperatorii

Introducere: Cancerul colorectal (CRC) se numără printre principalele cauze de deces cauzate de cancer în întreaga lume. Pacienții vârstnici sunt adesea considerați ca fiind o categorie cu risc crescut, predispuşi la complicații postoperatorii.

Materiale şi metode: 138 pacienți cu vârsta de peste 75 de ani şi diagnosticați cu cancer colorectal au fost revizuiți retrospectiv. Pacienții au fost împărțiți în două grupuri: Grupul de studiu pacienții care au dezvoltat complicații postoperatorii, şi Grupul de control - pacientii fără probleme în perioada postoperatorie. Au fost comparate date clinice, preoperatorii, chirurgicale, postoperatorii şi oncologice. Scopul studiului a fost de a determina posibili factori de risc în apariția complicațiilor postoperatorii şi de a analiza influența acestora asupra mortalității.

Rezultate: Factori de risc cum ar fi sexul bărbătesc, obezitate, insuficiența cardiacă, diabet zaharat tip II, anemie severă, hipoproteinemie, clasificare ASA III-IV, interventiile chirurgicale efectuate în urgență, timp operator îndelungat, sângerări semnificative intra-operatorie, internare prelungită, localizare distală a formațiunilor tumorale, stadiile TNM III-IV, antecedente de cancer digestiv operat sau alte operatii abdominale majore necanceroase efectuate au fost identificați.

Concluzii: Tratamentul chirurgical al cancerului colorectal în cazul populației cu vârstă înaintată rămâne o provocare, această categorie de pacienți trebuie să beneficieze de o atenție deosebită pentru a asigura o şansă de a minimaliza sau evita aceste complicații. 
Cuvinte cheie: vârstnici, cancer colorectal, complicații postoperatorii, evoluție nefavorabilă, atenție specială

\begin{abstract}
Introduction: Colorectal cancer (CRC) is among the leading causes of cancer-related deaths around the world. Elderly patients are often considered as a high-risk category of patients, predisposed for postoperative complications.

Materials and methods: 138 patients aged over 75 years and diagnosed with colorectal cancer were retrospectively reviewed. Patients were divided in two groups, as follows: Study Group including patients who developed postoperative complications, and Control Group including patients without problems in the postoperative period. There were compared clinical, preoperative, surgical, postoperative and oncological data. The aim of study was to determine possible risk factors for short-term postoperative complications and analyze of the influence of postoperative complications on survival.

Results: Risk factors as male gender, obesity, heart failure, diabetes type II, severe anemia, low total protein level, ASA III-IV classification, emergency surgery, prolonged surgical intervention, increased intraoperative blood loss, prolonged hospital stay, distal localization of tumors, TNM stages III-IV, surgery for digestive cancer and non-cancerous major abdominal surgery in the medical history were identified.

Conclusion: The surgical treatment of colorectal cancer in the aging population still remains a challenge, these category of patients should benefit of special attention in order to ensure a chance to minimize or avoid these complications.
\end{abstract}

Key words: elderly, colorectal cancer, postoperative complications, negative evolution, special attention

\section{Introduction}

Colorectal cancer (CRC) is among the leading causes of cancer-related deaths around the world, affecting same men and women. Despite the advances in surgical techniques and postoperative care, morbidity and mortality after surgery for colorectal cancer remains elevated. While life expectancy is increasing, the number of operations being performed on elderly patients is also growing, nearly one half of patients with colorectal cancer are aged over 70 years (1). However, elderly patients are often considered as a high-risk category of patients, predisposed for postoperative complications. Based on multiple studies, postoperative com- $^{-}$ plications occur in up to one-third of patients undergoing colorectal procedures (2). Advanced age is usually accompanied by underlying comorbidities, wich could seriously affect the outcomes of surgical treatment, furthermore these category of patients tend to present with more locally advanced or disseminated disease (3). In fact aging represents an independent risk factor after colorectal surgery for in-hospital morbidity and mortality as well, by reducing physiologicalrecuperative power (4). According to the previous, there can be stated that surgery for elderly with colorectal cancerhas become a major medical care issue.

\section{Materials and Methods}

\section{Aim of Study and Patient Selection}

The aim of the study was to determine possible risk factors for short-term postoperative complications during hospital stay in case of 
elderly patients with colorectal cancer. Furthermore, we analyzed the relationship between postoperative complications and survival, underlining the possible negative influence on the outcome of patients.

In 2018 we conducted a retrospective casecontrol study in which were included a total of 138 patientsaged over 75 years and diagnosed with colorectal cancer. Patients were admitted and followed surgical treatment at the $2^{\text {nd }}$ Department of General Surgery of Mureş County Emergency Clinical Hospital of Târgu Mureş. In the present study we have analyzed the clinical observation sheets, operatory and anatomopathological protocols.

\section{Subdivision of Patients and Collected Data}

In the first part of the study, patients were selected and divided in two groups, based on the presence or absence of postoperative complications, as follows: Group with Postoperative Complications (Study Group SG) - including 58 patients wich developed complications in the postoperative period, and Group without postoperative complications (Control Group - CG) - including 80 patients without postoperative difficulties.

In order to determine independent risk factors for postoperative complications in elderly with colorectal cancer, for all patients there were carefully gathered data from medical charts, operatory and anatomopathological protocols. The followed details contained clinical, preoperative status related, intraoperative, postoperative and oncological informations. Clinical characteristics included patient's age, gender and medical history, focusing mainly on cardiac, pulmonary and surgical diseases. Preoperative status was determined by presence of neoadjuvant oncologic therapy, laboratory findings such as Hemoglobin and Hematocrit level, Total Protein level and also by calculating ASA score (American Society of Anesthesiology Score). In order to ease analyze of preoperative anemia, there were separated three groups of bloodlessness, as follows: Mild Anemia $(\mathrm{Hb}>11 \mathrm{~g} / \mathrm{dl})$, Moderate Anemia $(\mathrm{Hb} \mathrm{8}-11 \mathrm{~g} / \mathrm{dl})$, Severe Anemia $(\mathrm{Hb}<8 \mathrm{~g} / \mathrm{dl})$. The analyzed surgical data comprised the character of surgery, location of the tumor, surgical intervention performed, necessity of stoma, presence of local invasion, presence of metastasis, intraoperative blood loss, need of intraoperative blood transfusion and duration of surgery. Regarding tumoral locations, there were distinguished right colon, left colon and rectal appearance of tumors. Right sided tumors containing malignancies of the cecum, ascending colon, liver flexure and transvers colon. Meantime left colon cancer involves splenic flexure, descending colon and sigmoid localization, while rectal localization of tumors were investigated separately. Three types of surgical interventions were separated, characterizing nature of surgical intervention: radical surgery, palliative intervention and inoperability. Radical surgery consisted of right hemicolectomy, left hemicolectomy, Reybard, Dixon and Miles operations, subtotal colectomy and the Hartmann's procedure during emergency interventions. Palliative surgical interventions were characterised by colostomy formation and limitation to internal derivation, while in some cases surgeons were forced to resign surgery, declaring inoperability of the case. In order to ease the classification of intraoperative blood loss, there were determined the following groups: Class I Hemorrhage $(<500 \mathrm{ml})$, Class II Hemorrhage (500-1000 ml), Class III Hemorrhage (1000-2000 ml) and Class IV Hemorrhage (> $2000 \mathrm{ml})$. Postoperative and oncologic data compared between the two groups included period of intensive therapy care, length of hospital stay and tumor staging.

In order to investigate the relationship between postoperative complications and possible negative evolution of patients, the second part of the study focused only on the group with postoperative complications (Study Group). Patients were evaluated and regrouped as follows: Patients with postoperative complications who deceased (DP) including 11 patients who deceased after suffering post-operative complications, respectively Patients with postoperative complications who survived (SP) - including 47 patients without fatal evolution after 
developing postoperative complications.

The purpose of this study was to evaluate the possible risk and protective factors for developing short-term postoperative complications. Because little is known about the impact of complications on patients mortality, this study also aimed to analyze whether a complicated postoperative evolution affects the survival in elderly patients.

\section{Statistical Analysis}

Collected information was processed using Microsoft Excel. The statistical analysis of the database was performed using Graph Pad InStat software (Graph Pad Software, Inc., San Diego, United States of America). Quantitative variables were presented by mean and median, while qualitative and categorical variables were expressed both as integer and percentage values. Anormality test was applied for all variable groups in order to determine the distribution of values. Furthermore, for the quantitative statistical analysis, Student's t-test was applied for groups with Gaussian distribution of values, while Mann-Whitney nonparametric test was used for groups with non-Gaussian distribution. Inferential statistical analysis involving odds ratios determination for mentioned clinical, surgical and postoperative factors was performed using Fisher's Exact Test. The level of statistical significance for the present research was set at a $\mathrm{p}$ value of 0.05 , while the confidence interval was $95 \%$ for all the calculated parameters.

\section{Results}

Table 1 shows the clinical characteristics and medical history and of patients, age being the first followed character. Mean age for SG was 76.87 years old, while in case of $\mathrm{CG}$, mean age was 76.65 years old, without statistical significance. Also, there was observed a higher percentage of male patients (SG - 75.86\%), male gender being a statistical significant risk factor for developing postoperative complica-

Table 1. Clinical data andpatients medical history

\begin{tabular}{|c|c|c|c|c|}
\hline $\begin{array}{l}\text { (Grou } \\
\text { comp }\end{array}$ & $\begin{array}{l}\text { Study Group } \\
\text { p with postoperative } \\
\text { lications) } n=58(\%)\end{array}$ & $\begin{array}{c}\text { Control Group } \\
\text { (Group without postoperative } \\
\text { complications) } n=80(\%)\end{array}$ & $\begin{array}{c}\mathrm{OR} \\
\text { (odds ratio) }\end{array}$ & $P$ value \\
\hline \multicolumn{5}{|l|}{ Age (years) } \\
\hline Mean & 76.87 & 76.65 & - & $0.4655 \mathrm{NS}$ \\
\hline \multicolumn{5}{|l|}{ Gender } \\
\hline Male & $44(75.86)$ & $37(46.25)$ & 3.653 & 0.0005 \\
\hline Female & $14(24.14)$ & $43(53.75)$ & 0.273 & 0.0005 \\
\hline \multicolumn{5}{|l|}{ Patients Medical History } \\
\hline Obesity & $20(34.48)$ & $8(10)$ & 4.737 & 0.0006 \\
\hline Arterial hypertension & $34(58.62)$ & $44(55)$ & 1.159 & $0.7294 \mathrm{NS}$ \\
\hline Ischemic cardiomyopathy & $36(62.07)$ & $42(52.5)^{\prime}$ & 1.481 & $0.2991 \mathrm{NS}$ \\
\hline Heart failure & $14(24.14)$ & $8(10)$ & 2.864 & 0.0337 \\
\hline Myocardial infarction & $2(3.45)$ & $6(7.5)$ & 0.440 & $0.4675 \mathrm{NS}$ \\
\hline Atrial fibrillation & $8(13.79)$ & $6(7.5)$ & 1.973 & $0.2617 \mathrm{NS}$ \\
\hline COBP & $4(6.9)$ & $2(2.5)$ & 2.889 & $0.2384 \mathrm{NS}$ \\
\hline Asthma & $0(0)$ & $1(1.25)$ & 0.453 & $1.0000 \mathrm{NS}$ \\
\hline Pulmonary embolism & $0(0)$ & $1(1.25)$ & 0.453 & $1.0000 \mathrm{NS}$ \\
\hline Diabetes Type I & $2(3.45)$ & $1(1.25)$ & 2.821 & $0.5723 \mathrm{NS}$ \\
\hline Diabetes Type II & $15(25.86)$ & $9(11.25)$ & 2.752 & 0.0392 \\
\hline Surgery for digestive cancer & $6(10.34)$ & $0(0)$ & 19.93 & 0.0047 \\
\hline $\begin{array}{l}\text { Other non-cancerous major } \\
\text { abdominal surgery }\end{array}$ & $21(36.21)$ & $17(21.25)$ & 2.103 & 0.0568 \\
\hline
\end{tabular}

NS - not significant $p$ value 
tions, with an $\mathrm{OR}=3.653$ and $\mathrm{P}=0.0005$. Female gender appeared to be a statistically significant protective factor in the occurrence of postoperative problems $(\mathrm{OR}=0.273, \mathrm{P}=$ 0.0005). While analyzing patients medical history, there were observed that obesity (OR $=4.737, \mathrm{P}=0.0006)$, heart failure $(\mathrm{OR}=2.864$, $\mathrm{P}=0.0337)$, diabetes type II $(\mathrm{OR}=2.752$, $\mathrm{P}=0.0392)$, surgery for digestive cancer $(\mathrm{OR}=$ 19.93, $\mathrm{P}=0.0047$ ) and other major abdominal surgery $(\mathrm{OR}=2.103, \mathrm{P}=0.0568)$ in the personal history increased the appearance of postoperative issues, being identified as independent risk factors for developing postoperative complications.

In Table 2 information about preoperative status are presented. Inspecting neoadjuvant oncologic treatment appeared without any statistical significance in the development of postoperative complications. Evaluation of preoperative anemia resulted mild anemia as a protective factor in the development of postoperative complications $(\mathrm{OR}=0.285, \mathrm{P}=$ 0.0309), while severe anemia at the time of hospital admission represented an important risk factor in the buildout of postoperative difficulties $(\mathrm{OR}=4.488, \mathrm{P}=0.0254)$. Furthermore, low total protein level resulted as a significant risk factor in the advancement of postoperative issues $(\mathrm{OR}=3.459, \mathrm{P}=$ 0.0010). The statistical analysis of ASA classification resulted in significant statistical parameters regarding postoperative complications for patients in ASA III-IV groups (OR = $4.875, \mathrm{P}=0.0001$ ), while ASA I-II categories were identified as protective factors in the development of postoperative problems $(\mathrm{OR}=$ $0.205, \mathrm{P}=0.0001$ ).

In Table 3 intraoperative assessments are shown. Statistical analysis of admission type resulted surgery in emergency conditions as a potential risk factor for developing postoperative complications $(\mathrm{OR}=2.676, \mathrm{P}=0.0171)$, while elective surgical interventions seemed to be significant protective factors against postoperative problems $(\mathrm{OR}=0.373, \mathrm{P}=0.0171)$. While examining the most frequent locations of colon tumors, there was detected that distal localization (rectum) of tumors were possible risk factors for postoperative complications $(\mathrm{OR}=2.239, \mathrm{P}=0.0252)$, meantime tumors of the proximal colon seemed to be protective factors in the development of postoperative issues ( $\mathrm{OR}=0.297, \mathrm{P}=0.0059)$. Analyzing the performed surgical interventions, resulted radical surgery as a potential protective factor in the development of postoperative complications $(\mathrm{OR}=0.320, \mathrm{P}=0.0531)$. Necessity of stoma during surgery was observed in $48.27 \%$ for Study Group, and $31.25 \%$ in case of Control Group, without any significant differences. Furthermore, local invasion of the

Table 2. Survey of preoperative status

\begin{tabular}{|c|c|c|c|c|}
\hline & $\begin{array}{c}\text { Study Group } \\
\text { (Group with postoperative } \\
\text { complications) } n=58(\%)\end{array}$ & $\begin{array}{c}\text { Control Group } \\
\text { (Group without postoperative } \\
\text { complications) } n=80(\%)\end{array}$ & $\begin{array}{c}\text { OR } \\
\text { (odds ratio) }\end{array}$ & $P$ value \\
\hline \multicolumn{5}{|c|}{ Neoadjuvant oncologic treatment } \\
\hline Chemotherapy & $6(10.34)$ & $2(2.5)$ & 4.500 & $0.0689 \mathrm{NS}$ \\
\hline Radiotherapy & $8(12.79)$ & $7(8.75)$ & 1.669 & 0.4112 NS \\
\hline \multicolumn{5}{|c|}{ Severity of preoperative anemia } \\
\hline Mild $(>11 \mathrm{~g} / \mathrm{dl})$ & $6(10.34)$ & $12(15)$ & 0.285 & 0.0309 \\
\hline Moderate $(8-11 \mathrm{~g} / \mathrm{dl})$ & 22 (37.93) & $17(21.25)$ & 1.022 & $1.0000 \mathrm{NS}$ \\
\hline Severe $(<8 \mathrm{~g} / \mathrm{dl})$ & $13(22.41)$ & $3(3.75)$ & 4.488 & 0.0254 \\
\hline \multicolumn{5}{|l|}{ Total Protein Level } \\
\hline $\begin{array}{l}\text { Low Protein Level } \\
\text { ASAClassification }\end{array}$ & $28(48.27)$ & $17(21.25)$ & 3.459 & 0.0010 \\
\hline ASA I-II & $16(27.59)$ & $52(65)$ & 0.205 & 0.0001 \\
\hline ASA III-IV & $42(72.41)$ & $28(35)$ & 4.875 & 0.0001 \\
\hline
\end{tabular}

NS - not significant $p$ value 
Table 3. Intraoperative assesment

\begin{tabular}{|c|c|c|c|c|}
\hline & $\begin{array}{c}\text { Study Group } \\
\text { (Group with postoperative } \\
\text { complications) } n=58(\%)\end{array}$ & $\begin{array}{c}\text { Control Group } \\
\text { (Group without postoperative } \\
\text { complications) } n=80(\%)\end{array}$ & $\begin{array}{c}\mathrm{OR} \\
\text { (odds ratio) }\end{array}$ & $P$ value \\
\hline \multicolumn{5}{|c|}{ Character of surgical intervention } \\
\hline Elective & $37(63.79)$ & $66(82.5)$ & 0.373 & 0.0171 \\
\hline Emergency & $21(36.21)$ & $14(17.5)$ & 2.676 & 0.0171 \\
\hline \multicolumn{5}{|l|}{ Tumor location } \\
\hline Right colon & $8(13.79)$ & $28(35)$ & 0.297 & 0.0059 \\
\hline Left colon & $16(27.59)$ & $21(26.25)$ & 1.070 & $1.0000 \mathrm{NS}$ \\
\hline Rectum & $34(58.62)$ & $31(38.75)$ & 2.239 & 0.0252 \\
\hline \multicolumn{5}{|l|}{ Surgery performed } \\
\hline Radical surgery & $48(82.76)$ & $75(93.75)$ & 0.320 & 0.0531 \\
\hline Paliative surgery & $8(13.79)$ & $5(6.25)$ & 2.400 & 0.1511 \\
\hline Inoperability & $2(3.45)$ & $0(0)$ & 7.124 & 0.1749 \\
\hline \multicolumn{5}{|l|}{ Need of stoma } \\
\hline Yes & $28(48.27)$ & $25(31.25)$ & 2.053 & 0.0518 \\
\hline No & $30(51.73)$ & $55(68.75)$ & 0.487 & 0.0518 \\
\hline \multicolumn{5}{|c|}{ Presence of local invasion } \\
\hline Yes & $26(44.83)$ & $28(35)$ & 1.509 & 0.2901 \\
\hline No & $32(55.17)$ & $52(65)$ & 0.662 & 0.2901 \\
\hline \multicolumn{5}{|l|}{ Presence of metastasis } \\
\hline Yes & $20(34.48)$ & $23(28.75)$ & 1.304 & 0.5768 \\
\hline No & $38(65.52)$ & $57(71.25)$ & 0.766 & 0.5768 \\
\hline \multicolumn{5}{|l|}{ Intraoperative blood loss } \\
\hline Class I Hemorrhage & $30(51.72)$ & $66(82.5)$ & 0.227 & 0.0002 \\
\hline Class II Hemorrhage & $22(37.93)$ & $11(13.75)$ & 3.833 & 0.0013 \\
\hline Class III Hemorrhage & $6(10.35)$ & $3(3.75)$ & 2.962 & 0.1658 \\
\hline Class IV Hemorrhage & $0(0)$ & $0(0)$ & - & - \\
\hline \multicolumn{5}{|c|}{ Need of intraoperative blood transfusion } \\
\hline Yes & $24(41.38)$ & $21(26.25)$ & 1.983 & 0.0684 \\
\hline No & $34(58.62)$ & $59(73.75)$ & 0.504 & 0.0684 \\
\hline \multicolumn{5}{|l|}{ Duration of surgery } \\
\hline$<90$ minutes & $7(12.07)$ & $13(16.25)$ & 0.707 & $0.6259 \mathrm{NS}$ \\
\hline $90-180$ minutes & $32(55.17)$ & $56(70)$ & 0.527 & $0.1059 \mathrm{NS}$ \\
\hline$>180$ minutes & $19(32.76)$ & $11(13.75)$ & 3.056 & 0.0115 \\
\hline
\end{tabular}

tumor and presence of metastasis resulted no statistically significant differences for the evaluated groups. High intraoperative blood loss (Class II Hemorrhage) resulted in significant statistical parameters regarding the risk of postoperative complications $(\mathrm{OR}=3.833, \mathrm{P}$ $=0.0013$ ), while low blood loss (Class I Hemorrhage) seemed to be a protective factor in the development of complications in the postoperative period $(\mathrm{OR}=0.227, \mathrm{P}=0.0002)$. The need of intraoperative blood transfusion had no significant influence on the postopera- tive evolution in case of both groups. Estimating the duration of surgery, longer operating time was demonstrated as a risk factor for postoperative complications, with an $\mathrm{OR}=3.056$ and $\mathrm{P}=0.0115$.

Table 4 presents the results observed while analyzing postoperative and oncologic data. A shorter intensive therapy stay (1-2 days) confirmed to be a protective factor in the appearance of postoperative complications $(\mathrm{OR}=0.077, \mathrm{P}=0.0319)$. Analyzing length of hospital admission resulted shorter 
Table 4. Postoperative and oncological data

\begin{tabular}{ccccc}
\hline & $\begin{array}{c}\text { Study Group } \\
\text { (Group with postoperative } \\
\text { complications) } \mathbf{n = 5 8} \text { (\%) }\end{array}$ & $\begin{array}{c}\text { Control Group } \\
\text { (Group without postoperative } \\
\text { complications) } \mathbf{n = 8 0}(\%)\end{array}$ & $\begin{array}{c}\text { OR } \\
\text { (odds ratio) }\end{array}$ & P value \\
\hline Intensive therapy care (days) & $14(24.1)$ & $7(8.75)$ & 0.077 & 0.0319 \\
\hline 1-2 days & $5(8.6)$ & $0(0)$ & 3.837 & $0.5591 \mathrm{NS}$ \\
$3-4$ days & $7(12.1)$ & $0(0)$ & 5.769 & 0.2994 NS \\
$>$ 4 days & & & \\
\hline Length of hospital stay (days) & 13.06 & 11.05 & - & - \\
\hline Mean & $19(32.76)$ & $41(51.25)$ & 0.463 & 0.0373 \\
1-7 days & $23(39.66)$ & $31(38.75)$ & 1.039 & 1.0000 NS \\
8-14 days & $16(27.58)$ & $8(10)$ & 3.429 & 0.0113 \\
$>$ 14 days & & & & \\
\hline TNM staging & $31(53.45)$ & $59(73.75)$ & 0.408 & 0.0184 \\
\hline Stadium I-II & $27(46.55)$ & $21(26.25)$ & 2.447 & 0.0184 \\
\hline Stadium III-IV & & & & \\
\hline
\end{tabular}

NS - not significant $p$ value

hospital stay (1-7 days) as a significant protective factor against postoperative problems with an $\mathrm{OR}=0.463$ and $\mathrm{P}=0.0373$, while a hospital stay above 14 days seemed to be risk factor in the development of complications in the postoperative period $(\mathrm{OR}=3.429, \mathrm{P}=0.0113)$. The statistical analysis of tumor stadium resulted in significant statistical parameters regarding the risk for postoperative complications in colorectal tumors with stage III-IV TNM (OR $=2.447, \mathrm{P}=0.0184)$. Meantime tumoral stages I-II found to be protective factors in the development of postoperative issues, with an $\mathrm{OR}=0.408$ and $\mathrm{P}=0.0184$.

The possible negative effects of postoperative complications on survival are presented in Table 5 and Fig. 1. For this section of the study patients were regrouped depending on mortality, as mentioned before. Analyzing the established complications, there were found that cardiovascular $(\mathrm{OR}=5.727, \mathrm{P}=$ $0.0250)$, respiratory $(\mathrm{OR}=11.762, \mathrm{P}=$ $0.0387)$ and renal $(\mathrm{OR}=4.762, \mathrm{P}=0.0387)$ complications had the biggest negative impact on the evolution of elder patients.

Table 5. Postoperative complications affecting survival

\begin{tabular}{lcccc}
\hline & $\begin{array}{c}\text { DP } \\
\text { (Patients with postoperative } \\
\text { complications who deceased) } \\
\mathbf{n = 1 1 ( \% )}\end{array}$ & $\begin{array}{c}\text { SP } \\
\text { (Patients with postoperative } \\
\text { complications who survived) } \\
\mathbf{n = 4 7}(\%)\end{array}$ & $\begin{array}{c}\text { OR } \\
\text { (odds } \\
\text { ratio) }\end{array}$ & P value \\
\hline Type of postoperative complication & & & & \\
\hline Wound infection & $0(0)$ & $2(4.25)$ & 0.791 & 1.0000 NS \\
\hline Intraabdominal abscess & $0(0)$ & $4(8.51)$ & 0.420 & 1.0000 NS \\
\hline Anastomotic leakage & $1(9.09)$ & $3(6.38)$ & 1.467 & 1.0000 NS \\
\hline Bowel occlusion & $1(9.09)$ & $10(21.28)$ & 0.370 & $0.6708 \mathrm{NS}$ \\
\hline Intraabdominal bleeding & $4(36.36)$ & $5(10.64)$ & 4.800 & 0.0560 \\
\hline Cardiovascular & $7(63.63)$ & $11(23.40)$ & 5.727 & 0.0250 \\
\hline Respiratory & $9(81.82)$ & $13(27.66)$ & 11.769 & 0.0015 \\
Renal & $5(45.45)$ & $7(14.89)$ & 4.762 & 0.0387 \\
Evisceration & $1(9.09)$ & $2(4.25)$ & 2.250 & $0.4745 \mathrm{NS}$ \\
\hline
\end{tabular}

NS - not significant $p$ value 


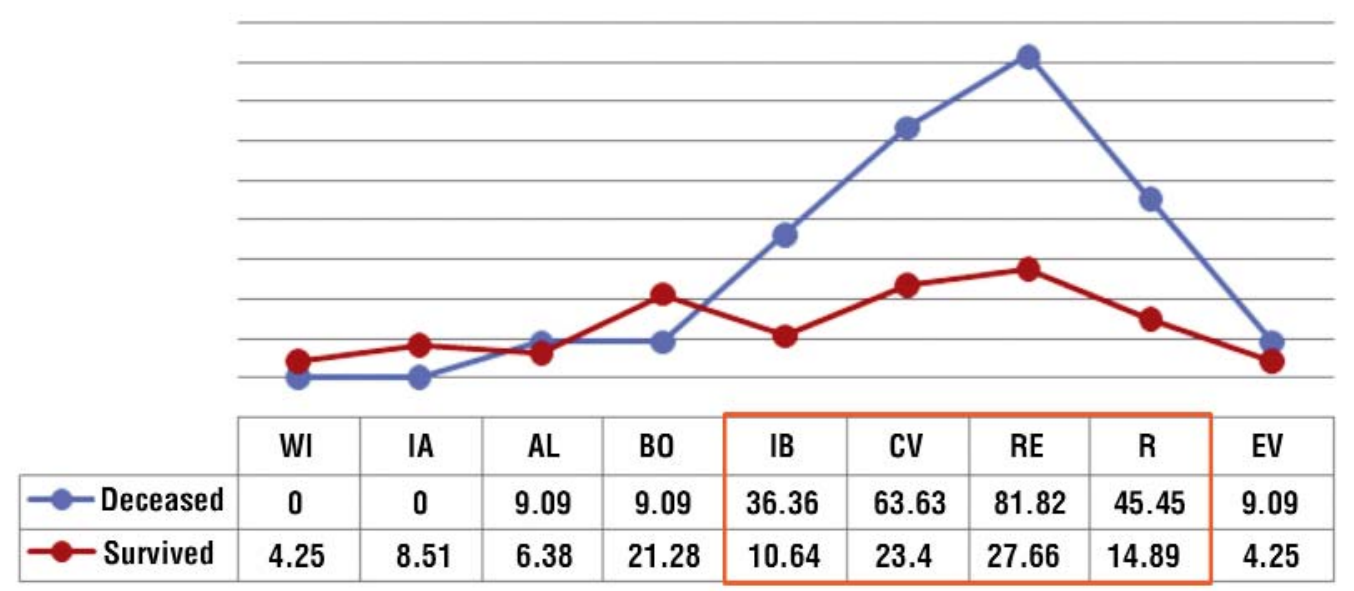

Figure 1. Percentage of occurred complications and their impact on survival WI - Wound Infection, IA - Intraabdominal Abscess, AL - Anastomotic Leakage, BO - Bowel Occlusion, IB - Intraoperatory bleeding, CV - Cardiovascular, RE - Respiratory, R - Renal, EV - Evisceration

\section{Discussion}

\section{Evaluation of Clinical Data and Patients Medical History}

The first evaluated aspects were patients clinical data and medical history. While evaluating clinical characteristics of the studied groups, age and gender where the first followed aspects. Mean age was calculated for both groups, with average of 76.87 years for Study Group and 76.65 years in case of Control Group. An increased risk for developing postoperative complications was observed with aging, patients over 76 years old presenting a possible risk factor, these findings being similar to other author's reports (5). During inspection regarding patients gender, there were identified more male patients in the Study group ( $75.86 \%$ ), concluding that male gender is an independent risk factor for the occurrence of postoperative complications. Other authors reported similar results (6). While analyzing patients medical history,we focused mostly on cardiac (arterial hypertension, ischemic cardiomyopathy, heart failure, myocardial infarction, atrial fibrillation), pulmonary (COBP, Asthma, Pulmonary embolism), diabetic (Type I and II), surgical (Surgery for digestive cancer, Other noncancerous major abdominal surgery) and obesity related data. There was observed, that obese patients were more likely predisposed for postoperative complications, $34.48 \%$ of patients from Study Group had an increased BMI. Furthermore, heart failure and diabetes type II were identified as independent risk factors in the development of negative postoperative evolution. Statistical analysis of prior surgery for digestive cancer or non-cancerous major abdominal surgery resulted as significant risk factors for unfavorable outcome during the postoperative period. In addition, diabetes type I, chronic pulmonary disease and atrial fibrillation presented increased percentages for developing postoperative complications, being potential risk factors for postoperative issues, however not significant statistically, due to the small number of patients. Similar results regarding the influence of patients medical history, on postoperative outcome, can be found in the literature of specialty (7-13).

\section{Survey of Preoperative Status}

In order to avoid or minimalize appearance of post-surgical issues, determination of patients general status before colorectal cancer surgery, represents an obligatory step. We evaluated the presence of preoperative anemia, low total protein level, neoadjuvant oncologic therapy 
and also ASA score was calculated. While examining the presence of neoadjuvant oncologic treatment, there was noticed that a higher percentage of patients benefited of radiotherapy ( $\mathrm{SG}-12.79 \%, \mathrm{CG}-8.75 \%$ ), while chemotherapy was applied in $10.34 \%$ in case of SG and only $2.5 \%$ for CG, without statistical significance in case of both groups. However, an increased OR for postoperative complications was remarked for patients from Study Group. Similar aspects can be found in other surgical articles to (14). Investigating preoperative anemia concluded that majority of patients from Study Group presented moderate or severe anemia (Moderate Anemia $37.93 \%$, Severe Anemia $22.41 \%$ ), while in case of patients from Control Group anemia at the time of hospital admission was present in lower percentages. Based on the related, there can be stated that preoperative severe anemia increased the risk for appearance of postoperative complications, while mild anemia confirmed to be a protective factor in the development of negative postoperative evolution. Others reported close results to ours (15). Analyzing total protein level, there can be observed that almost half of patients $(48.27 \%)$ who presented complications in the postoperative period had lower levels of total protein. Therefore, low total protein level at the time of hospital admission was identified as a significant risk factor for postoperative complications. Comparable results can be found in the literature of specialty (16). There was also noticed that ASA I-II stages were identified as protective factors, while more advanced stages of ASA classifications (III-IV) were recognized as independent risk factors for developing postoperative complications. Close results to ours can be found in similar articles $(17,18)$.

\section{Analysis of Surgical Details}

While inspecting surgical assessment, nature of surgical intervention was the first aspect to follow. There were observed a majority of elective surgeries for both of the studied groups, aspect which confirmed to be a protective factor against the appearance of post- operative complications. In case of Study Group, $36.21 \%$ of patients were admitted in emergency condition and benefitted of immediate surgical care, while in case of Control Group, only $17.5 \%$ of patients presented at the emergency unit. However, surgery in emergency surroundings resulted to be an independent risk factor for developing postoperative problems. Other authors reported same results to ours (19). The majority of tumors were localized in the distal part of large bowel and the rectum. Analyzing these data resulted rectal localization being a statistically significant risk factor for potential poor postoperative outcome. There can be found close result to ours (20). Performed surgery was also investigated, focusing on the character of practiced interventions, whether it was a radical operation, just palliative surgery or inoperability forced the surgeons to abort any surgical treatment. Among operations, radical surgery was performed in the highest percentage. Patients who benefited of palliative surgery or inoperability was diagnosed, presented an increased possibility for postoperative complications. Surprisingly, patients who underwent radical surgical intervention seemed to be associated with a decreased incidence of postoperative complications, likely due to the small number of patients. Aspect, which is contrary with the literature of specialty (21). The influence of protective or permanent stoma on the appearance of postoperative complications was also analyzed, observing an increased possibility for postoperative problems in case of patients with stomas, however, no statistical difference was observed for both of the studied groups. Analyzing local invasion of the tumor or presence of metastasis were not associated with any influence on the development of postoperative complications. The assessment of intraoperative blood loss showed an increased risk for developing postoperative complications for patients with increased bleeding during surgical intervention (Class II and III Hemorrhage), while less quantity of blood loss (Class I Hemorrhage) confirmed to be a protective factor in the occurrence of postoperative complications. Other authors report 
the same results (22). The necessity of intraoperative blood transfusion displayed a potential risk for possible negative postoperative evolution, but not significant from statistical point of view, probably due to the small number of patients. However, other authors stated the same (23). Operating time is well known to contribute to patients postoperative evaluation and prognosis. While analyzing operating time during the present study, there was observed a negative influence on postoperative outcome for patients with prolonged surgical intervention. Close results with ours can be found in the literature of specialty (24).

\section{Postoperative Data}

Postoperative assessment investigated the potential involvement of the intensive therapy abidance, length of hospital stay and tumoral stages in the occurrence of postoperative complications in studied patients. As there was expected, a favorable postoperative outcome was identified in case of patients with minimal intensive therapy stay, while extended necessity of intensive unite therapy was determined as a possible risk factor for postoperative obstacles, although statistically not significant due to the reduced number of patients. Results close to ours can be found in similar articles (25). Average length of hospital stay was higher for patients from Study Group, representing a mean of 13 days. We also observed, that reduced hospital stay had a favorable influence on patients, regarding the occurrence of postoperative complications. Although not significant from statistical point of view, but prolonged hospital stay was identified as a possible risk factor for negative postoperative events. Same result can be found in similar articles (26). Tumoral staging (TNM) had itself influence on the postoperative outcome of patients, incipient stages of malignant tumors (Stage I-II) confirmed to be a protective factor in the development of postoperative complications. Patients who were suffering from advanced stages of cancer, presented in higher percentage postoperative complications, proving that stages III-IV of cancer are significant risk factors for negative postoperative outcome. Similar effects can be red in major surgical articles (27).

\section{Occurred Complications During Hospital Stay}

During the study there were identified multiple types of complications during the postoperative period, which influenced the outcome of elderly patients. Colorectal operations are contaminated procedures, in many cases peritoneal cavity and wound surfaces contamination happens. In the present study $4.25 \%$ of patients presented wound infections. Antibiotic prophylaxis plays a major role in preventing these types of complications.Intraabdominal abscess occurred in $8.51 \%$ of patients, making reoperation and an effective drainage necessary. Appearance of anastomotic leakage still remains one of the most feared complications possible of digestive cancer surgery, leading to peritonitis and in some cases toabdominal compartment syndrome, presenting a significant negative influence on patients survival. Early decision of reoperation should be made if necessary, in order to improve patients outcome (28). Occurrence of bowel occlusion prolongs hospital stay and increases morbidity of patients. Treatment is sometimes difficult, early diagnosis and proper surgical care has major benefits in patients evolution. Evisceration occurred only in three cases, without an important influence on postoperative mortality, although it represents a serious condition, which needs special attention and careful treatment. According to the present study, intraabdominal bleeding, cardiovascular, respiratory and renal complications were the most frequent and feared postoperative issues occurred after colorectal surgery, with negative influence on the survival of elderly patients. Generally postoperative intraabdominal bleeding is a rare condition and depends mostly on the surgical procedure performed. Accurate postoperative follow up can highlight abnormal heart rate, low blood pressure and modified Hemoglobin, Hematocrit values. Preoperative careful selection of patients could spotlight 
underlying cardiovascular disease. Patients early mobilization could avoid appearance of pneumonia, proper anticoagulant prophylaxis can rule out blood clothing and embolization. As a summary, the overall complication rate was $42.02 \%$, while mortality represented $7.97 \%$ and was statistically significant in favor of patients who presented post-operative complications. Aspects stated before can be found in multiple studies (28-33).

\section{Short-Term Postoperative Complications Affecting Survival}

For the last section of the study, patients were regrouped as follows: Patients with postoperative complications who deceased (DP) and Patients with postoperative complications who survived (SP), willing to prove the influence of postoperative complications on the prognosis of studied patients. There was observed, that patients who developed complications during the postoperative period, were exposed to high risk for decease in relation to patients without postoperative complications. Other published reports being similar to our findings $(34,35)$.

\section{Conclusion}

The surgical treatment of colorectal cancer in the aging population still remains a challenge, which has got its own characteristics. The outcomes of colorectal surgery in geriatric patients is uncertain, occurred postoperative complications increase the morbidity and mortality rates. Proper surgical treatment of these category of patients requires an optimal knowledge of the factors influencing the outcome of surgical procedures. Based on the presented study we believe, that management of CRC in elderly patients requires a careful approach and a personalized strategy for treatment. In the preoperative period an optimal risk assessment is necessary in order to exclude patients from surgery based on the morbidity, or to determine the required preoperative care adjusted to the patient's clinical
Table 6. Summary - Identified risk factors

\begin{tabular}{c|l}
\hline No & $\begin{array}{l}\text { Risk factors for developing postoperative } \\
\text { complications in elderly patients with } \\
\text { colorectal cancer }\end{array}$ \\
\hline 1 & Male Gender \\
\hline 2 & Obesity \\
\hline 3 & Heart Failure \\
\hline 4 & Diabetes Type II \\
\hline 5 & Severe Anemia \\
\hline 6 & Low Total Protein Level \\
\hline 7 & ASA III-IV Classification \\
\hline 8 & Emergency Surgery \\
\hline 9 & Prolonged Surgery \\
\hline 10 & Increased Intraoperative Blood Loss \\
\hline 11 & Longer Hospital Stay \\
\hline 12 & Distal Localization of Tumor \\
\hline 13 & TNM Stages Ill-IV of Tumor \\
\hline 14 & Surgery for Digestive Cancer in Medical History \\
\hline 15 & Other Non-Cancerous Major Abdominal Surgery in \\
\hline
\end{tabular}

and physical status. Furthermore, a proper evaluation of preoperative nutritional and cardiopulmonary status has got a major importance to avoid possible negative postoperative evolution. In all cases accent should be put on prevention, early identification, and avoiding of perioperative complications. For patients with considerable comorbidities, a multidisciplinary approach may be chosen in order to optimize the preoperative condition and also to prevent development of postoperative complications. Elderly patients suffering from postoperative complications after colorectal surgery should benefit of special attention in order to offer the best chance for survival. In order to ensure a chance to minimize or avoid these complications it is crucial to know the major risk factors, based on which surgeons can work out different strategies to prevent or reduce the negative influence of postoperative complications. Major risk factors which influence postoperative complication rate are summarized in Table 6.

For performing this study ethical approval was obtained. 


\section{Conflict of Interest}

The authors declare no conflicts of interests.

\section{References}

1. Bosetti C, Bertuccio P, Malvezzi M, Levi F, Chatenoud L, Negri E, et al. Cancer mortality in Europe, 2005-2009, and an overview of trends since 1980. Ann Oncol, 2013;24(10):2657-71.

2. Alves A, Panis Y, Mathieu P, Mantion G, Kwiakowski F, Slim K. Postoperative mortality and morbidity in French patients undergoing colorectal surgery: results of a postoperative multicenter study. Arch Surg, 2005; 140(3): 278-283.

3. Tabola R, Mantese G, Cirocchi R, Gemini A, Grassi V, Boselli C, et al. Postoperative mortality and morbidity in older patients undergoing emergency right hemicolectomy for colon cancer. Aging Clin Exp Res. 2017;29(Suppl 1):121-126.

4. Jafari MD, Jafari F, Halabi WJ, Nguyen VQ, Pigazzi A, Carmichael $\mathrm{JC}$, et al. Colorectal cancer resections in the aging US population: A trend toward decreasing rates and improved outcomes. JAMA Surg. 2014;149(6):557-64.

5. Marusch F, Koch A, Schmidt U, Steinert R, Ueberrueck T, Bittner R, et al. The impact of the risk factor age on the early postoperative results of surgery for colorectal carcinoma and its significance for perioperative management. World J Surg. 2005; 29(8):1013-21.

6. Kirchhoff P, Dincler S, Buchmann P. A multivariate analysis pf potential risk factors for intra- and postoperative complications in 1316 elective laparoscopic colorectal procedures. Ann Surg. 2008; 248(2):259-65.

7. Poelemeijer YQM, Lijftogt $\mathrm{N}$, Detering R, Fiocco $\mathrm{M}$, Tollenaar RAEM, Wouters MWJM. Obesity as a determinant of perioperative and postoperative outcome in patients following colorectal cancer surgery: A population-based study (2009-2016). Eur J Surg Oncol. 2018; 44(12): 1849-1857.

8. Franko J, O'Connell BG, Mehall JR, Harper SG, Nejman JH, Zebley $D M$, et al. The influence of prior abdominal operations on conversion and complication rates in laparoscopic colorectal surgery. JSLS. 2006;10(2):169-75.

9. Aquina CT, Mohile SG, Tejani MA, Becerra AZ, Xu Z, Hensley BJ, et al. The impact of age on complications, survival and cause of death following colon cancer surgery. Br J Cancer. 2017;116(3):389-397.

10. Caroline Yao, Guy F Nash, Tamas Hickish. Management of colorectal cancer and diabetes. J R Soc Med. 2014:107(3):103-109.

11. Raymond Yap, Simon Wilkins, Margaret Staples, Karen Oliva, Paul $\mathrm{J}$ McMurrick. The effect of diabetes on the perioperative outcomes of colorectal cancer surgery patients. PLoS One. 2016;11(12): e0167271.

12. Dale CD, McLoone P, Sloan B, Kinsella J, Morrison D, Puxty K, et al. Critical care provision after colorectal cancer surgery. BMC Anesthesiol. 2016;16(1):94.

13. Corrado Pedrazzani, Guido Cerullo, Giovanni De Marco, Daniele Marrelli, Alessandro Neri, Alfonso De Stefano, et al. Impact of agerelated comorbidity on results of colorectal cancer surgery. World J Gastroenterol. 2009; 15(45): 5706-11.

14. Huang L, Li TJ, Zhang JW, Liu S, Fu BS, Liu W. Neoadjuvant chemotherapy followed by surgery versus surgery alone for colorectal cancer. Medicine (Baltimore). 2014;93(28):e231.

15. Dunne JR, Malone D, Tracy JK, Gannon C, Napolitano LM. Preoperative anemia: an independent risk factor for infection, mortality and resource utilization in surgery. J Surg Res. 2002; 102:237-44.

16. Truong A, Hanna MH, Moghadamyeghaneh Z, Stamor MJ Implications of preoperative hypoalbuminemia in colorectal surgery. World J Gastrointest Surg. 2016;8(5):353-362.

17. Kim YW, Kim IY. Factors associated with postoperative complications and 1-year mortality after surgery for colorectal cancer in octo-genarians and nonagenarians. Clin Interv Aging. 2016; 11:689-697.

18. Park JH, Kim DH, Kim BR, Kim YW. The American Society of Anesthesiologists score influences on postoperative complications and total hospital charges after laparoscopic colorectal cancer surgery. Medicine (Baltimore). 2018:97(18):e0653.

19. HJ Ng, M Yule, M Twoon, NR Binnie, EH Aly. Current outcome of emergency larga bowel surgery. Ann R Coll Surg Engl. 2015;97(2): 151-156.

20. van der Slip MPL, Bastiaannet E, Mesker WE, van der Geest LGM, Breugom AJ, Steup WH. Differences between colon and rectal cancer in complications, short-term survival and recurrences. Int J Colorectal Dis. 2016; 31(10):1683-1691.

21. Campos FG, Calijuri Hamra MC, Imperiale AR, Kiss DR, Nahas SC, Cecconello I. Locally advanced colorectal cancer: results of surgical treatment and prognostic factors. Arq Gastroenterol. 2011;48(4): 270-5.

22. Chen Z, Zheng Z, He X, He X, Lan P. Surgery for elder patients with colorectal cancer and risk factors for postoperative complication. AJCEM. 2018; 6(4): 103-106.

23. Wu HL, Tai YH, Lin SP, Chan MY, Chen HH, Chang KY. The impact of blood transfusion on recurrence and mortality following colorectal cancer resection: a propensity score analysis of 4.030 patients. Scientific Reports. 2018;8:13345.

24. Harrison OJ, Smart NJ, White P, Brigic A, Carlisle ER, Allison AS, et al. Operative time and outcome of enhanced recovery after surgery after laparoscopic colorectal surgery. JSLS. 2014;18(2):265-72.

25. Aksov Y, Kaydu A, Sahin OF, Kacar CK, et al. Analysis of cancer patients admitted to intensive care unit. North Clin Istanb. 2016; 3(3): 217-221.

26. Dekker JW, Gooiker GA, Bastiaannet E, van den Broek CB, van der GEES LG, van de Velde CJ, et al. Cause of death the first year after curative colorectal cancer surgery, a prolonged impact of the surgery in elderly colorectal cancer patients. Eur J Surg Oncol. 2014; 40(11): 1481-7.

27. Kim IY, Kim BR, Kim HS, Kim YW. Differences in clinical features between laparoscopy and open resection for primary tumor in patients with stage IV colorectal cancer. Onco Targets Ther. 2015; 8:3441-3448

28. Muresan M, Muresan S, Branzaniuc K, Voidazan S, Sala D, Jimborean 0 , et al. How much does decompressive laparotomy reduce the mortality rate in primary abdominal compartment syndrome? Medicine (Baltimore). 2017; 96(5): e6006

29. Tevis SE, Kennedy GD. Postoperative complications: looking forward to a safer future. Clin Colon Rectal Surg. 2016; 29(3):246252.

30. Grosso G, Biondi A, Marventano S, Mistretta A, Calabrese G, Basile F. Major postoperative complications and survival for colon cancer elderly patients. BMC Surg. 2012;12(Suppl 1):S20.

31. Neagoe RM, D Sala, Voidazan S, Bancu S, Kiss L, Suciu H. Transthoracic versus transhiatal esophagectomy: a permanent dilemma. Our 15-year experience. Chirurgia. 2013;108(6):780-787.

32. Fagard K, Casaer J, Wolthuis A, Flamaing J, Milisen K, Lobelle JP, et al. Postoperative complications in individuals aged 70 and over undergoing elective surgery for colorectal cancer. Colorectal Dis. 2017;19(9):0329-0338.

33. Kirchhoff P, Clavien PA, Hahnloser D. Complications in colorectal surgery: risk factors and preventive strategies. Patient Saf Surg. 2010;4:5

34. Aoyama T, Oba K, Honda M, Sadahiro S, Hamada C, Mayanagi S, et al. Impact of postoperative complications on the colorectal cancer survival and recurrence: analyses of pooled individual patients data from three large phase III randomized trials. Cancer Med. 2017; 6(7):1573-1580.

35. Latkauskas $T$, Rudinskaite $G$, Kurtinaitis J, Janciauskiene $R$, Tamelis A, Saladzinskas Z, et al. The impact of age on postoperative outcomes of colorectal cancer patients undergoing surgical treatment. BMC Cancer. 2005;5:153. 